\title{
System Study: High-Pressure Core Spray 1998-2012
}

T. E. Wierman

October 2013

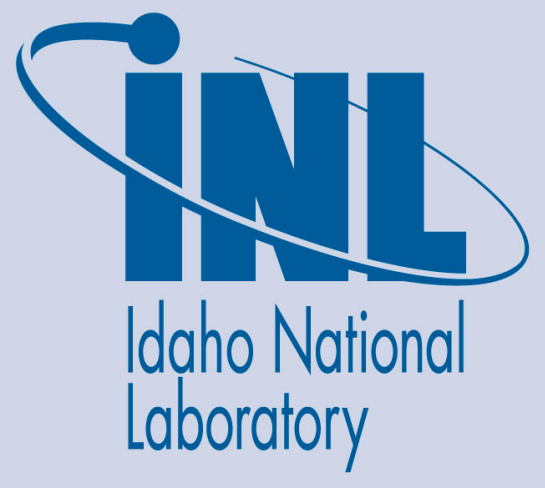

The INL is a U.S. Department of Energy National Laboratory operated by Battelle Energy Alliance 
INL/EXT-14-31132

\title{
System Study: High-Pressure Core Spray 1998-2012
}

\author{
T. E. Wierman
}

October 2013

Update Completed September 2013

\section{Idaho National Laboratory \\ Risk Assessment and Management Services Department Idaho Falls, Idaho 83415}

http://www.inl.gov

Prepared for the Division of Risk Assessment

Office of Nuclear Regulatory Research

U.S. Nuclear Regulatory Commission

Washington, D.C. 20555

Job Code N6631 
NOTICE

This information was prepared as an account of work sponsored by an agency of the U.S. Government. Neither the U.S. Government nor any agency thereof, nor any of their employees, makes any warranty, express or implied, or assumes any legal liability or responsibility for any third party's use, or the results of such use, of any information, apparatus, product, or process disclosed herein, or represents that its use by such third party would not infringe privately owned rights. The views expressed herein are not necessarily those of the U.S. Nuclear Regulatory Commission. 



\begin{abstract}
This report presents an unreliability evaluation of the high-pressure core spray (HPCS) at 8 U.S. commercial boiling water reactors. Demand, run hours, and failure data from fiscal year 1998 through 2012 for selected components were obtained from the Equipment Performance and Information Exchange (EPIX). The unreliability results are trended for the most recent 10-year period while yearly estimates for system unreliability are provided for the entire active period. No statistically significant increasing or decreasing trends were identified in the HPCS results.
\end{abstract}




\section{CONTENTS}

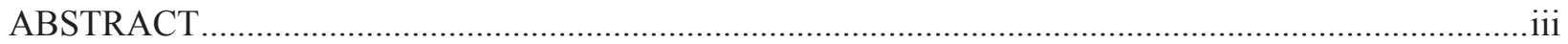

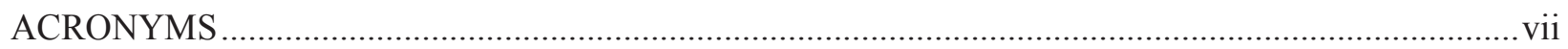

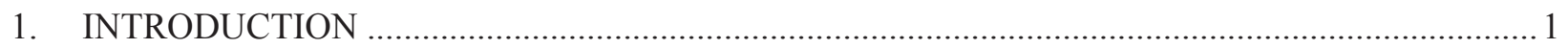

2. SUMMARY OF FINDINGS ……………………………………………………………...

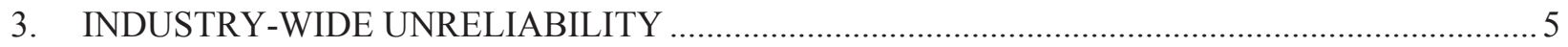

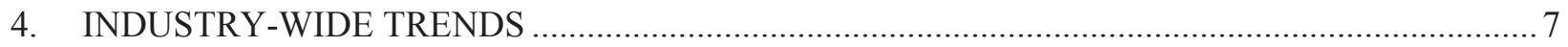

5. BASIC EVENT GROUP IMPORTANCES …………………………………………….....

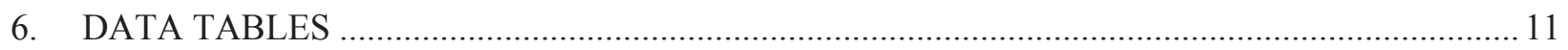

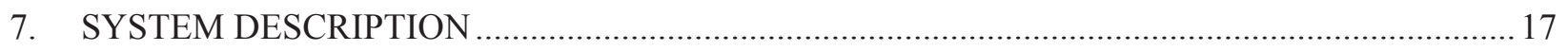

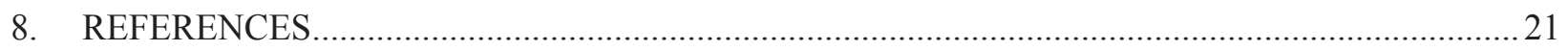

\section{FIGURES}

1. Trend of HPCS system unreliability (start-only model), as a function of fiscal year.......................... 8

2. Trend of HPCS system unreliability ( 8 -hour model), as a function of fiscal year................................ 8

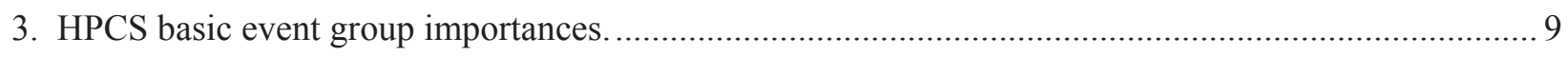

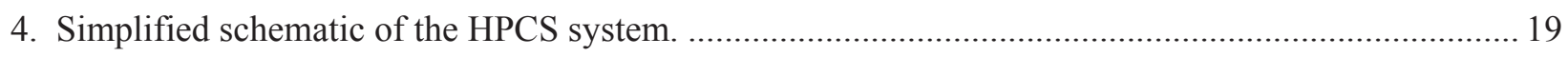

\section{TABLES}

1. BWR plants with a HPCI system selected for the study............................................................ 2

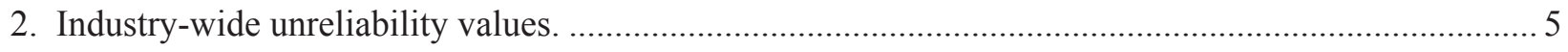

3. HPCS model basic event importance group descriptions. ........................................................... 10

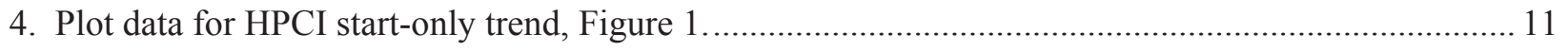

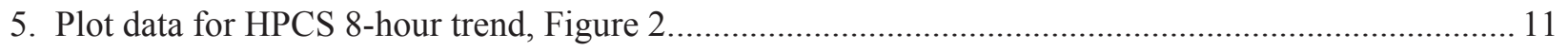




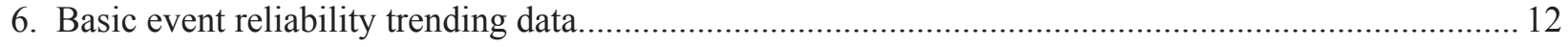

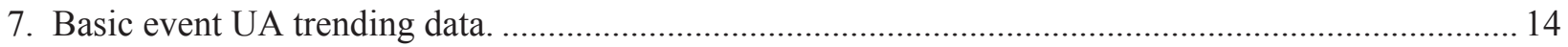

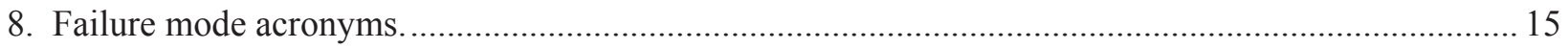

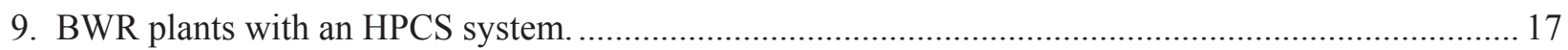




\section{ACRONYMS}

\begin{tabular}{|c|c|}
\hline ADS & automatic depressurization system \\
\hline BWR & boiling water reactor \\
\hline $\mathrm{CCF}$ & common-cause failure \\
\hline EPIX & Equipment Performance and Information Exchange \\
\hline FY & fiscal year \\
\hline $\begin{array}{l}\text { HPCI } \\
\text { HPCS }\end{array}$ & $\begin{array}{l}\text { high-pressure coolant injection } \\
\text { high-pressure core spray }\end{array}$ \\
\hline $\begin{array}{l}\text { LOCA } \\
\text { LOOP } \\
\text { LPCI } \\
\text { LPCS }\end{array}$ & $\begin{array}{l}\text { loss-of-coolant accident } \\
\text { loss-of-offsite power } \\
\text { low-pressure coolant injection } \\
\text { low-pressure core spray }\end{array}$ \\
\hline MSPI & Mitigating Systems Performance Index \\
\hline PRA & probabilistic risk assessment \\
\hline $\begin{array}{l}\text { RCIC } \\
\text { RPV }\end{array}$ & $\begin{array}{l}\text { reactor core isolation cooling } \\
\text { reactor pressure vessel }\end{array}$ \\
\hline $\begin{array}{l}\text { SPAR } \\
\text { SSU }\end{array}$ & $\begin{array}{l}\text { standardized plant analysis risk } \\
\text { safety system unavailability }\end{array}$ \\
\hline
\end{tabular}


System Study

High-Pressure Core Spray
2012 Update October 2013 


\section{System Study: High-Pressure Core Spray 1998-2012}

\section{INTRODUCTION}

This report presents an unreliability evaluation of the high-pressure core spray (HPCS) system at 8 U.S. commercial boiling water reactors (BWRs) listed in Table 1. For each plant, the corresponding Standardized Plant Analysis Risk (SPAR) model (version model indicated in Table 1) was used in the yearly calculations. Demand, run hours, and failure data from fiscal year (FY)-98 through FY-12 for selected components in the HPCS system were obtained from the Equipment Performance and Information Exchange (EPIX) database. Train unavailability data (outages from test or maintenance) were obtained from the Reactor Oversight Process Safety System Unavailability (SSU) database (FY-98 through FY-01) and the Mitigating Systems Performance Index (MSPI) database (FY-02 through FY-12). Common-cause failure (CCF) data used in the models are from the 2010 update to the CCF database. The system unreliability results are trended for the most recent 10 -year period while yearly estimates for system unreliability are provided for the entire active period.

This report does not attempt to estimate basic event values for use in a probabilistic risk assessment (PRA). Suggested values for such use are presented in the 2010 Component Reliability Update (Reference 1), which is an update to Reference 2 (NUREG/CR-6928). Baseline HPCS unreliability results using basic event values from that report are summarized in Section 3. Trend results for HPCS (using system-specific data) are presented in Section 4. Similar to previous system study updates, Section 0 contains importance information (using the baseline results from Section 3), and Section 7 describes the HPCS.

The HPCS model is evaluated using the large loss-of-coolant accident (LOCA) and the loss-of-offsite power (LOOP) flag sets in the SPAR model (setting the LOOP flag requires the start and run of the HPCS diesel generator). The LOOP flag set assumes all ac power is unavailable and that the HPCS system is required to perform to mitigate the effects of the LOOP initiating event. All models include failures due to unavailability while in test or maintenance. Human error has not been included in the SPAR model logic. An overview of the trending methods, glossary of terms, and abbreviations can be found in the Overview and Reference document on the Reactor Operational Experience Results and Databases web page.

Two modes of the models for the HPCS system are calculated. The HPCS start-only model is modified by setting all fail-to-run basic events to zero (False), setting the suction transfer events to False, and setting all cooling basic events to False. The 8-hour mission model includes all basic events in the SPAR HPCS model. 
Table 1. BWR plants with a HPCI system selected for the study.

\begin{tabular}{lc}
\hline \multicolumn{1}{c}{ Plant } & Version \\
\hline Clinton 1 & 8.17 \\
Columbia 2 & 8.16 \\
Grand Gulf & 8.22 \\
La Salle 1 & 8.21 \\
La Salle 2 & 8.21 \\
Nine Mile Pt. 2 & 8.17 \\
Perry & 8.19 \\
River Bend & 8.20 \\
\hline
\end{tabular}




\section{SUMMARY OF FINDINGS}

The results of this HPCS system unreliability study are summarized in this section. Of particular interest is the existence of any statistically significant $t^{\mathrm{a}}$ increasing trends. In this update, no statistically significant increasing trends were identified in the HPCS unreliability trend results. In addition, this update identified no statistically significant decreasing trends in the HPCS results.

The industry-wide HPCS start-only and 8-hour basic event group importances were evaluated and are shown in Figure 3. In both cases, the leading contributors to HPCS system unreliability are the diesel generator, the HPCS pump, and special events. Cooling support is important in the 8-hour model.

a Statistically significant is defined in terms of the 'p-value.' A p-value is a probability indicating whether to accept or reject the null hypothesis that there is no trend in the data. P-values of less than or equal to 0.05 indicate that we are $95 \%$ confident that there is a trend in the data (reject the null hypothesis of no trend.) By convention, we use the "Michelin Guide" scale: p-value $<0.05$ (statistically significant), p-value $<0.01$ (highly statistically significant); pvalue $<0.001$ (extremely statistically significant). 
System Study

High-Pressure Core Spray
2012 Update October 2013 


\section{INDUSTRY-WIDE UNRELIABILITY}

The HPCS fault trees from the SPAR models were evaluated for each of the eight operating U.S. commercial boiling water nuclear power plants with an HPCS system.

The industry-wide unreliability of the HPCS system has been estimated for two modes of operation. A start-only model and an 8-hour mission model were evaluated. The uncertainty distributions for HPCS show both plant design variability and parameter uncertainty while using industry-wide component failure data (1998-2010). ${ }^{\text {a }}$ Table 2 shows the percentiles and mean of the aggregated sample data (Latin hypercube, 1000 samples for each model) collected from the uncertainty calculations of the HPCS fault trees in the SPAR models.

Table 2. Industry-wide unreliability values.

\begin{tabular}{ccccc}
\hline Model & Lower (5\%) & Median & Mean & Upper (95\%) \\
\hline Start & $7.77 \mathrm{E}-03$ & $2.53 \mathrm{E}-02$ & $2.57 \mathrm{E}-02$ & $4.63 \mathrm{E}-02$ \\
8-hour & $9.64 \mathrm{E}-03$ & $5.03 \mathrm{E}-02$ & $4.85 \mathrm{E}-02$ & $9.20 \mathrm{E}-02$ \\
\hline
\end{tabular}

a. By using industry-wide component failure data, individual plant performance is not included in the distribution of results. 
System Study

High-Pressure Core Spray 


\section{INDUSTRY-WIDE TRENDS}

The yearly (FY-98 through FY-12) failure and demand or run time data were obtained from EPIX for the HPCS system. HPCS train maintenance unavailability data for trending are from the same time period, as reported in the ROP and EPIX. The component basic event uncertainty was calculated for the HPCS system components using the trending methods described in Section 1 and 2 of the Overview and Reference document. Tables 6 and 7 show the yearly data values for each HPCS system specific component and failure mode combination that was varied in the model. These data were loaded into the HPCS system fault tree in each SPAR model with a HPCS system (see Table 1).

The trend charts show the results of varying component reliability data over time and updating generic, relatively-flat prior distributions using data for each year. In addition, for comparison, the calculated industry-wide system reliability from this update (current SPAR/EPIX) is shown. Section 4 of the Overview and Reference link on the System Studies main web page provides more detailed discussion of the trending methods. In the lower left hand corner of the trend figures, the regression method is reported.

The components that were varied in the HPCS model are

- HPCS diesel generator start, run, and test and maintenance.

- HPCS motor-driven pump start, run, and test and maintenance.

- HPCS motor-operated valve, fail to operate.

Figure 1 shows the trend in the start-only model unreliability. Table 4 shows the data points for Figure 1. No statistically significant trends within the industry-wide estimates of HPCS system unreliability (start-only) on a per fiscal year basis were identified.

Figure 2 shows the trend in the 8-hour mission unreliability. No statistically significant trend within the industry-wide estimates of HPCS system unreliability (8-hour mission) on a per fiscal year basis was identified. Table 5 shows the data points for Figure 2. 


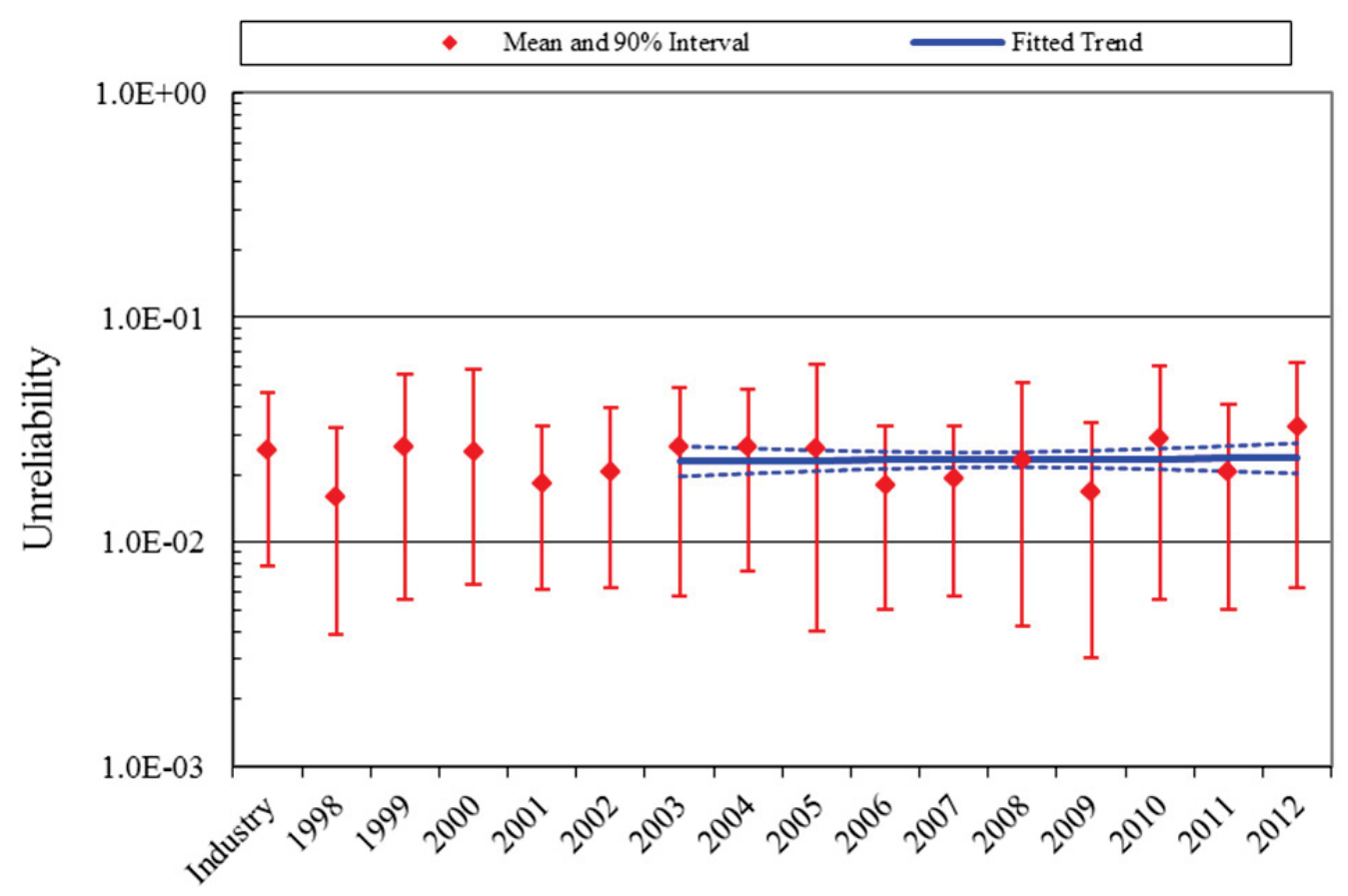

Logit model, $\mathrm{p}$-value $=0.3669 \quad$ Fiscal Year Industry HPCS Start-Only 9-19-2013

Figure 1. Trend of HPCS system unreliability (start-only model), as a function of fiscal year.

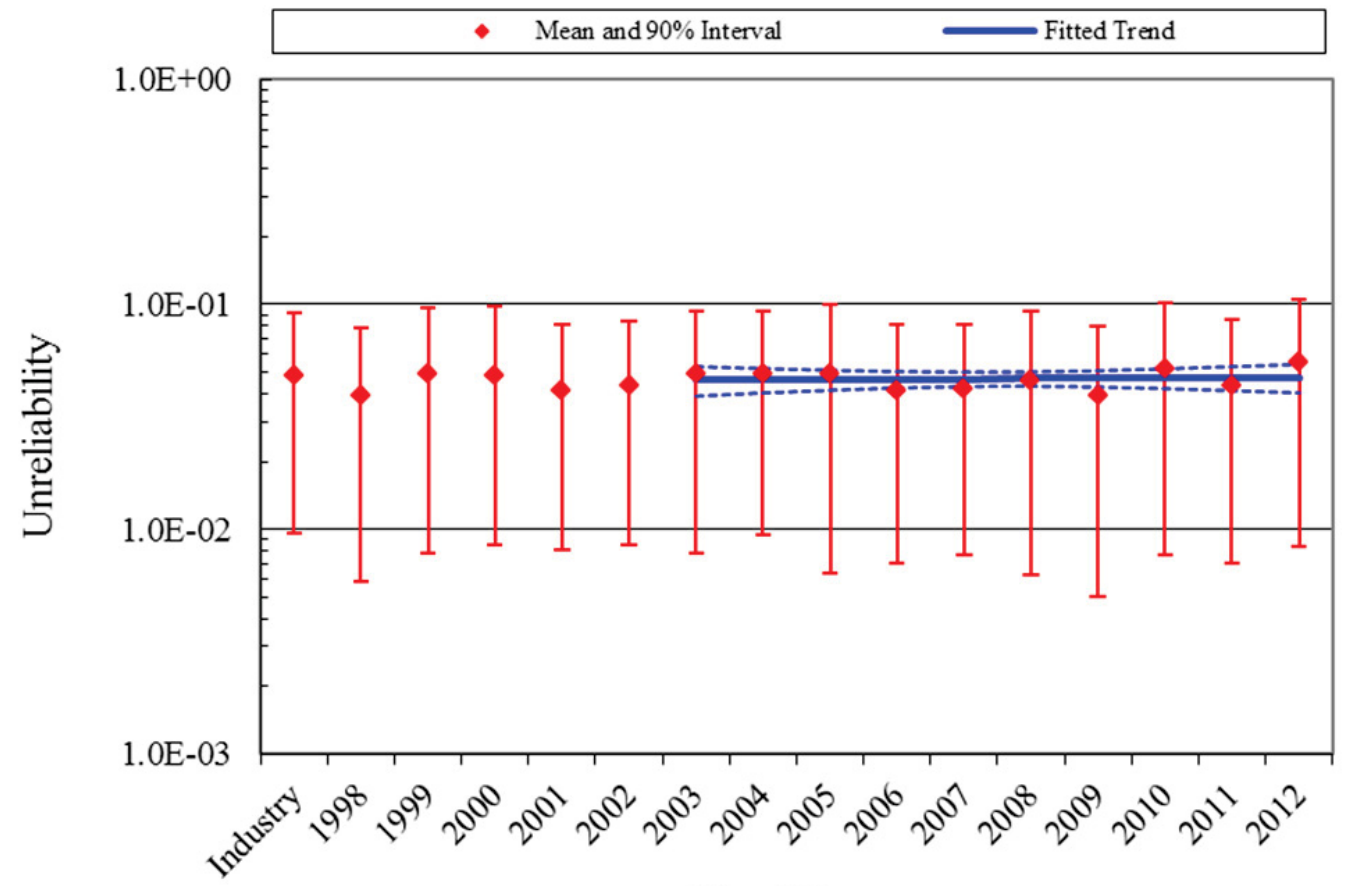

Fiscal Year

Linear model, p-value $=0.3619 \quad$ Industry HPCS 8-hour 9-19-2013

Figure 2. Trend of HPCS system unreliability (8-hour model), as a function of fiscal year. 


\section{BASIC EVENT GROUP IMPORTANCES}

The HPCS basic event group Fussell-Vesely importances were calculated for the start-only and 8hour models for each plant using the industry-wide data (1998-2010). These basic event group importances were then averaged across all plants to represent an industry-wide basic event group importance.

The industry-wide HPCS start-only and 8-hour basic event group importances are shown in Figure 3. In both cases, the leading contributors to HPCS system unreliability are the diesel generator, the HPCS pump, and special events. Cooling support is important in the 8-hour model. For more discussion on the HPCS motor-driven pumps and diesel generators, see the motor-driven pump and diesel generator component reliability studies at NRC Reactor Operational Experience Results and Databases. Table 3 shows the SPAR model HPCS importance groups and their descriptions.

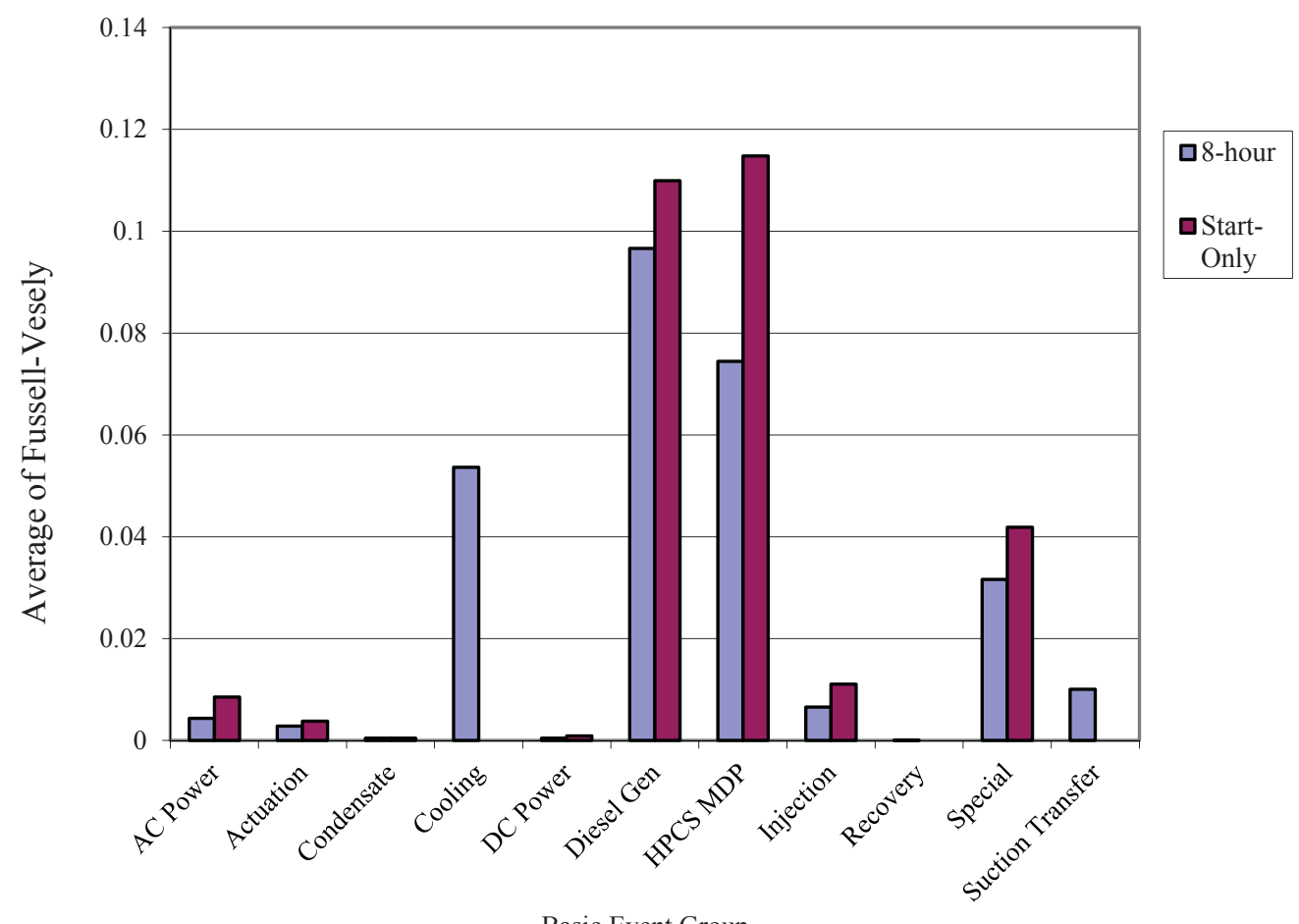

Figure 3. HPCS basic event group importances. 
Table 3. HPCS model basic event importance group descriptions.

\begin{tabular}{|c|c|}
\hline Group & Description \\
\hline AC Power & $\begin{array}{l}\text { The ac buses and circuit breakers that supply power to the HPCS pump and other } \\
\text { loads. }\end{array}$ \\
\hline Actuation & ESF actuation circuitry. \\
\hline Condensate & $\begin{array}{l}\text { The motor-operated valves and air-operated valves in the condensate storage } \\
\text { tank suction path. Includes the failure of the condensate storage tank. }\end{array}$ \\
\hline Cooling & $\begin{array}{l}\text { The pumps, valves, and heat exchangers that provide heat removal to the HPCS } \\
\text { motor-driven pump and the HPCS room. }\end{array}$ \\
\hline DC Power & $\begin{array}{l}\text { The batteries and battery chargers that supply power to the HPCS motor -driven } \\
\text { pump control circuitry. }\end{array}$ \\
\hline Diesel Gen & $\begin{array}{l}\text { All basic events associated with the primary emergency power supplies. Includes } \\
\text { diesel, gas turbine, and hydro powered equipment. The start, run, common- } \\
\text { cause, and test and maintenance are included in the group of basic events. }\end{array}$ \\
\hline HPCS MDP & $\begin{array}{l}\text { All basic events associated with the motor-driven pumps. The start, run, } \\
\text { common-cause, and test and maintenance are included in the group of basic } \\
\text { events. }\end{array}$ \\
\hline Injection & The motor-operated valves and check valves in the HPCS injection path. \\
\hline Recovery & $\begin{array}{l}\text { This group contains the events that allow operator recovery from expected } \\
\text { automatic actions. }\end{array}$ \\
\hline Special & $\begin{array}{l}\text { Various events used in the models that are not directly associated with the HPCS } \\
\text { system. }\end{array}$ \\
\hline Suction Transfer & $\begin{array}{l}\text { The suppression pool motor-operated valves, check valves, and strainers required } \\
\text { when a need to transfer to the suppression pool (torus) occurs. }\end{array}$ \\
\hline
\end{tabular}




\section{DATA TABLES}

Table 4. Plot data for HPCI start-only trend, Figure 1.

\begin{tabular}{ccccccc}
\hline & \multicolumn{2}{c}{ Regression Curve Data Points } & \multicolumn{2}{c}{ Plot Trend Error Bar Points } \\
\cline { 2 - 7 } FY/Source & Mean & $\begin{array}{c}\text { Lower } \\
\mathbf{( 5 \% )}\end{array}$ & $\begin{array}{c}\text { Upper } \\
\mathbf{( 9 5 \% )}\end{array}$ & $\begin{array}{c}\text { Lower } \\
\mathbf{( 5 \% )}\end{array}$ & $\begin{array}{c}\text { Upper } \\
\mathbf{( 9 5 \% )}\end{array}$ & Mean \\
\hline SPAR/ EPIX & & & & $7.77 \mathrm{E}-03$ & $4.63 \mathrm{E}-02$ & $2.57 \mathrm{E}-02$ \\
1998 & & & & $3.90 \mathrm{E}-03$ & $3.25 \mathrm{E}-02$ & $1.58 \mathrm{E}-02$ \\
1999 & & & & $5.59 \mathrm{E}-03$ & $5.61 \mathrm{E}-02$ & $2.64 \mathrm{E}-02$ \\
2000 & & & & $6.44 \mathrm{E}-03$ & $5.84 \mathrm{E}-02$ & $2.52 \mathrm{E}-02$ \\
\hline 2001 & & & & $6.14 \mathrm{E}-03$ & $3.31 \mathrm{E}-02$ & $1.83 \mathrm{E}-02$ \\
2002 & & & & $6.24 \mathrm{E}-03$ & $3.94 \mathrm{E}-02$ & $2.06 \mathrm{E}-02$ \\
\hline 2003 & $2.29 \mathrm{E}-02$ & $1.96 \mathrm{E}-02$ & $2.68 \mathrm{E}-02$ & $5.71 \mathrm{E}-03$ & $4.84 \mathrm{E}-02$ & $2.65 \mathrm{E}-02$ \\
2004 & $2.30 \mathrm{E}-02$ & $2.02 \mathrm{E}-02$ & $2.62 \mathrm{E}-02$ & $7.37 \mathrm{E}-03$ & $4.78 \mathrm{E}-02$ & $2.64 \mathrm{E}-02$ \\
\hline 2005 & $2.31 \mathrm{E}-02$ & $2.07 \mathrm{E}-02$ & $2.57 \mathrm{E}-02$ & $4.00 \mathrm{E}-03$ & $6.16 \mathrm{E}-02$ & $2.59 \mathrm{E}-02$ \\
2006 & $2.32 \mathrm{E}-02$ & $2.12 \mathrm{E}-02$ & $2.53 \mathrm{E}-02$ & $5.01 \mathrm{E}-03$ & $3.29 \mathrm{E}-02$ & $1.80 \mathrm{E}-02$ \\
\hline 2007 & $2.32 \mathrm{E}-02$ & $2.15 \mathrm{E}-02$ & $2.51 \mathrm{E}-02$ & $5.77 \mathrm{E}-03$ & $3.31 \mathrm{E}-02$ & $1.92 \mathrm{E}-02$ \\
2008 & $2.33 \mathrm{E}-02$ & $2.16 \mathrm{E}-02$ & $2.52 \mathrm{E}-02$ & $4.20 \mathrm{E}-03$ & $5.14 \mathrm{E}-02$ & $2.33 \mathrm{E}-02$ \\
\hline 2009 & $2.34 \mathrm{E}-02$ & $2.14 \mathrm{E}-02$ & $2.55 \mathrm{E}-02$ & $3.07 \mathrm{E}-03$ & $3.41 \mathrm{E}-02$ & $1.66 \mathrm{E}-02$ \\
\hline 2010 & $2.35 \mathrm{E}-02$ & $2.11 \mathrm{E}-02$ & $2.61 \mathrm{E}-02$ & $5.55 \mathrm{E}-03$ & $6.12 \mathrm{E}-02$ & $2.87 \mathrm{E}-02$ \\
\hline 2011 & $2.36 \mathrm{E}-02$ & $2.07 \mathrm{E}-02$ & $2.68 \mathrm{E}-02$ & $5.01 \mathrm{E}-03$ & $4.12 \mathrm{E}-02$ & $2.07 \mathrm{E}-02$ \\
\hline 2012 & $2.36 \mathrm{E}-02$ & $2.02 \mathrm{E}-02$ & $2.76 \mathrm{E}-02$ & $6.22 \mathrm{E}-03$ & $6.26 \mathrm{E}-02$ & $3.24 \mathrm{E}-02$ \\
\hline
\end{tabular}

Table 5. Plot data for HPCS 8-hour trend, Figure 2.

\begin{tabular}{ccccccc}
\hline & \multicolumn{2}{c}{ Regression Curve Data Points } & \multicolumn{2}{c}{ Plot Trend Error Bar Points } \\
\cline { 2 - 7 } FY/Source & Mean & $\begin{array}{c}\text { Lower } \\
\mathbf{( 5 \% )}\end{array}$ & $\begin{array}{c}\text { Upper } \\
\mathbf{( 9 5 \% )}\end{array}$ & $\begin{array}{c}\text { Lower } \\
\mathbf{( 5 \% )}\end{array}$ & $\begin{array}{c}\text { Upper } \\
\mathbf{( 9 5 \% )}\end{array}$ & Mean \\
\hline SPAR/ EPIX & & & & $9.64 \mathrm{E}-03$ & $9.20 \mathrm{E}-02$ & $4.85 \mathrm{E}-02$ \\
1998 & & & & $5.84 \mathrm{E}-03$ & $7.89 \mathrm{E}-02$ & $3.90 \mathrm{E}-02$ \\
\hline 1999 & & & & $7.86 \mathrm{E}-03$ & $9.70 \mathrm{E}-02$ & $4.92 \mathrm{E}-02$ \\
\hline 2000 & & & & $8.58 \mathrm{E}-03$ & $9.83 \mathrm{E}-02$ & $4.81 \mathrm{E}-02$ \\
\hline 2001 & & & & $8.03 \mathrm{E}-03$ & $8.11 \mathrm{E}-02$ & $4.14 \mathrm{E}-02$ \\
\hline 2002 & & & & $8.50 \mathrm{E}-03$ & $8.42 \mathrm{E}-02$ & $4.36 \mathrm{E}-02$ \\
\hline 2003 & $4.60 \mathrm{E}-02$ & $3.95 \mathrm{E}-02$ & $5.35 \mathrm{E}-02$ & $7.83 \mathrm{E}-03$ & $9.29 \mathrm{E}-02$ & $4.93 \mathrm{E}-02$ \\
\hline 2004 & $4.61 \mathrm{E}-02$ & $4.06 \mathrm{E}-02$ & $5.23 \mathrm{E}-02$ & $9.35 \mathrm{E}-03$ & $9.26 \mathrm{E}-02$ & $4.91 \mathrm{E}-02$ \\
\hline 2005 & $4.62 \mathrm{E}-02$ & $4.16 \mathrm{E}-02$ & $5.12 \mathrm{E}-02$ & $6.40 \mathrm{E}-03$ & $9.95 \mathrm{E}-02$ & $4.89 \mathrm{E}-02$ \\
\hline 2006 & $4.63 \mathrm{E}-02$ & $4.25 \mathrm{E}-02$ & $5.04 \mathrm{E}-02$ & $7.02 \mathrm{E}-03$ & $8.11 \mathrm{E}-02$ & $4.12 \mathrm{E}-02$ \\
\hline 2007 & $4.64 \mathrm{E}-02$ & $4.30 \mathrm{E}-02$ & $5.00 \mathrm{E}-02$ & $7.73 \mathrm{E}-03$ & $8.16 \mathrm{E}-02$ & $4.23 \mathrm{E}-02$ \\
\hline 2008 & $4.65 \mathrm{E}-02$ & $4.31 \mathrm{E}-02$ & $5.01 \mathrm{E}-02$ & $6.27 \mathrm{E}-03$ & $9.30 \mathrm{E}-02$ & $4.61 \mathrm{E}-02$ \\
\hline 2009 & $4.66 \mathrm{E}-02$ & $4.28 \mathrm{E}-02$ & $5.07 \mathrm{E}-02$ & $5.00 \mathrm{E}-03$ & $8.05 \mathrm{E}-02$ & $3.97 \mathrm{E}-02$ \\
\hline 2010 & $4.67 \mathrm{E}-02$ & $4.21 \mathrm{E}-02$ & $5.18 \mathrm{E}-02$ & $7.64 \mathrm{E}-03$ & $1.02 \mathrm{E}-01$ & $5.14 \mathrm{E}-02$ \\
\hline 2011 & $4.68 \mathrm{E}-02$ & $4.12 \mathrm{E}-02$ & $5.31 \mathrm{E}-02$ & $7.05 \mathrm{E}-03$ & $8.60 \mathrm{E}-02$ & $4.36 \mathrm{E}-02$ \\
\hline 2012 & $4.69 \mathrm{E}-02$ & $4.03 \mathrm{E}-02$ & $5.45 \mathrm{E}-02$ & $8.33 \mathrm{E}-03$ & $1.04 \mathrm{E}-01$ & $5.49 \mathrm{E}-02$ \\
\hline
\end{tabular}


Table 6. Basic event reliability trending data.

\begin{tabular}{|c|c|c|c|c|c|c|c|c|}
\hline \multirow{2}{*}{$\begin{array}{l}\text { Failure } \\
\text { Mode }\end{array}$} & \multirow[b]{2}{*}{ Component } & \multirow[b]{2}{*}{ Year } & \multirow{2}{*}{$\begin{array}{l}\text { Number of } \\
\text { Failures }\end{array}$} & \multirow{2}{*}{$\begin{array}{l}\text { Demands/ } \\
\text { Run Hours }\end{array}$} & \multicolumn{4}{|c|}{ Bayesian Update } \\
\hline & & & & & Mean & Post A & Post B & Distribution \\
\hline FTLR & GEN & 1998 & 0 & 112.5 & $3.28 \mathrm{E}-03$ & 2.8 & 843.6 & Beta \\
\hline FTLR & GEN & 1999 & 1 & 120.2 & $4.42 \mathrm{E}-03$ & 3.8 & 850.3 & Beta \\
\hline FTLR & GEN & 2000 & 0 & 126.6 & $3.22 \mathrm{E}-03$ & 2.8 & 857.7 & Beta \\
\hline FTLR & GEN & 2001 & 0 & 121.2 & $3.24 \mathrm{E}-03$ & 2.8 & 852.3 & Beta \\
\hline FTLR & GEN & 2002 & 1 & 125.9 & $4.39 \mathrm{E}-03$ & 3.8 & 856.0 & Beta \\
\hline FTLR & GEN & 2003 & 0 & 130.0 & $3.21 \mathrm{E}-03$ & 2.8 & 861.1 & Beta \\
\hline FTLR & GEN & 2004 & 1 & 130.7 & 4.36E-03 & 3.8 & 860.8 & Beta \\
\hline FTLR & GEN & 2005 & 0 & 120.7 & $3.25 E-03$ & 2.8 & 851.8 & Beta \\
\hline FTLR & GEN & 2006 & 0 & 122.7 & $3.24 \mathrm{E}-03$ & 2.8 & 853.8 & Beta \\
\hline FTLR & GEN & 2007 & 0 & 120.4 & $3.25 \mathrm{E}-03$ & 2.8 & 851.5 & Beta \\
\hline FTLR & GEN & 2008 & 0 & 140.9 & 3.17E-03 & 2.8 & 872.0 & Beta \\
\hline FTLR & GEN & 2009 & 0 & 116.4 & $3.26 \mathrm{E}-03$ & 2.8 & 847.5 & Beta \\
\hline FTLR & GEN & 2010 & 1 & 135.5 & 4.34E-03 & 3.8 & 865.6 & Beta \\
\hline FTLR & GEN & 2011 & 0 & 121.3 & $3.24 \mathrm{E}-03$ & 2.8 & 852.4 & Beta \\
\hline FTLR & GEN & 2012 & 1 & 137.9 & 4.33E-03 & 3.8 & 868.0 & Beta \\
\hline FTR & GEN & 1998 & 0 & 202.6 & $1.02 \mathrm{E}-03$ & 3.6 & 3469.6 & Gamma \\
\hline FTR & GEN & 1999 & 1 & 279.4 & $1.28 \mathrm{E}-03$ & 4.6 & 3546.4 & Gamma \\
\hline FTR & GEN & 2000 & 0 & 220.6 & $1.02 \mathrm{E}-03$ & 3.6 & 3487.6 & Gamma \\
\hline FTR & GEN & 2001 & 0 & 199.6 & $1.02 \mathrm{E}-03$ & 3.6 & 3466.6 & Gamma \\
\hline FTR & GEN & 2002 & 0 & 199.8 & $1.02 \mathrm{E}-03$ & 3.6 & 3466.8 & Gamma \\
\hline FTR & GEN & 2003 & 0 & 290.1 & 9.99E-04 & 3.6 & 3557.1 & Gamma \\
\hline FTR & GEN & 2004 & 0 & 193.0 & $1.03 \mathrm{E}-03$ & 3.6 & 3460.0 & Gamma \\
\hline FTR & GEN & 2005 & 1 & 272.6 & $1.29 \mathrm{E}-03$ & 4.6 & 3539.6 & Gamma \\
\hline FTR & GEN & 2006 & 0 & 221.8 & $1.02 \mathrm{E}-03$ & 3.6 & 3488.8 & Gamma \\
\hline FTR & GEN & 2007 & 0 & 196.7 & $1.03 E-03$ & 3.6 & 3463.7 & Gamma \\
\hline FTR & GEN & 2008 & 0 & 321.1 & $9.90 \mathrm{E}-04$ & 3.6 & 3588.1 & Gamma \\
\hline FTR & GEN & 2009 & 0 & 222.4 & $1.02 \mathrm{E}-03$ & 3.6 & 3489.4 & Gamma \\
\hline FTR & GEN & 2010 & 1 & 275.4 & $1.29 \mathrm{E}-03$ & 4.6 & 3542.4 & Gamma \\
\hline FTR & GEN & 2011 & 0 & 274.9 & $1.00 \mathrm{E}-03$ & 3.6 & 3541.9 & Gamma \\
\hline FTR & GEN & 2012 & 0 & 158.7 & $1.04 \mathrm{E}-03$ & 3.6 & 3425.7 & Gamma \\
\hline $\mathrm{FTR}<1 \mathrm{H}$ & MDP & 1998 & 0 & 99.4 & $1.22 \mathrm{E}-04$ & 1.8 & 14889.4 & Gamma \\
\hline $\mathrm{FTR}<1 \mathrm{H}$ & MDP & 1999 & 0 & 122.7 & $1.22 \mathrm{E}-04$ & 1.8 & 14912.7 & Gamma \\
\hline $\mathrm{FTR}<1 \mathrm{H}$ & MDP & 2000 & 0 & 110.2 & $1.22 \mathrm{E}-04$ & 1.8 & 14900.2 & Gamma \\
\hline $\mathrm{FTR}<1 \mathrm{H}$ & MDP & 2001 & 0 & 94.5 & $1.22 \mathrm{E}-04$ & 1.8 & 14884.5 & Gamma \\
\hline $\mathrm{FTR}<1 \mathrm{H}$ & MDP & 2002 & 0 & 121.7 & $1.22 \mathrm{E}-04$ & 1.8 & 14911.7 & Gamma \\
\hline $\mathrm{FTR}<1 \mathrm{H}$ & MDP & 2003 & 0 & 181.1 & $1.22 \mathrm{E}-04$ & 1.8 & 14971.1 & Gamma \\
\hline FTR $<1 \mathrm{H}$ & MDP & 2004 & 0 & 126.6 & $1.22 \mathrm{E}-04$ & 1.8 & 14916.6 & Gamma \\
\hline $\mathrm{FTR}<1 \mathrm{H}$ & MDP & 2005 & 0 & 151.3 & $1.22 \mathrm{E}-04$ & 1.8 & 14941.3 & Gamma \\
\hline $\mathrm{FTR}<1 \mathrm{H}$ & MDP & 2006 & 0 & 122.1 & $1.22 \mathrm{E}-04$ & 1.8 & 14912.1 & Gamma \\
\hline $\mathrm{FTR}<1 \mathrm{H}$ & MDP & 2007 & 0 & 101.8 & $1.22 \mathrm{E}-04$ & 1.8 & 14891.8 & Gamma \\
\hline FTR<1H & MDP & 2008 & 0 & 131.3 & $1.22 \mathrm{E}-04$ & 1.8 & 14921.3 & Gamma \\
\hline
\end{tabular}


Table 6. (continued).

\begin{tabular}{|c|c|c|c|c|c|c|c|c|}
\hline \multirow{2}{*}{$\begin{array}{l}\text { Failure } \\
\text { Mode }\end{array}$} & \multirow[b]{2}{*}{ Component } & \multirow[b]{2}{*}{ Year } & \multirow{2}{*}{$\begin{array}{l}\text { Number of } \\
\text { Failures }\end{array}$} & \multirow{2}{*}{$\begin{array}{l}\text { Demands/ } \\
\text { Run Hours }\end{array}$} & \multicolumn{4}{|c|}{ Bayesian Update } \\
\hline & & & & & Mean & Post A & Post B & Distribution \\
\hline $\mathrm{FTR}<1 \mathrm{H}$ & MDP & 2009 & 0 & 88.4 & $1.22 \mathrm{E}-04$ & 1.8 & 14878.4 & Gamma \\
\hline $\mathrm{FTR}<1 \mathrm{H}$ & MDP & 2010 & 0 & 109.8 & $1.22 \mathrm{E}-04$ & 1.8 & 14899.8 & Gamma \\
\hline $\mathrm{FTR}<1 \mathrm{H}$ & MDP & 2011 & 1 & 92.9 & $1.89 \mathrm{E}-04$ & 2.8 & 14882.9 & Gamma \\
\hline $\mathrm{FTR}<1 \mathrm{H}$ & MDP & 2012 & 0 & 97.2 & $1.22 \mathrm{E}-04$ & 1.8 & 14887.2 & Gamma \\
\hline FTR $>1 \mathrm{H}$ & MDP & 1998 & 0 & 2230.2 & $1.01 \mathrm{E}-05$ & 0.8 & 77240.2 & Gamma \\
\hline $\mathrm{FTR}>1 \mathrm{H}$ & MDP & 1999 & 0 & 1555.6 & $1.02 \mathrm{E}-05$ & 0.8 & 76565.6 & Gamma \\
\hline FTR $>1 \mathrm{H}$ & MDP & 2000 & 0 & 75.9 & $1.04 \mathrm{E}-05$ & 0.8 & 75085.9 & Gamma \\
\hline $\mathrm{FTR}>1 \mathrm{H}$ & MDP & 2001 & 0 & 75.6 & $1.04 \mathrm{E}-05$ & 0.8 & 75085.6 & Gamma \\
\hline $\mathrm{FTR}>1 \mathrm{H}$ & MDP & 2002 & 0 & 59.4 & $1.04 \mathrm{E}-05$ & 0.8 & 75069.4 & Gamma \\
\hline FTR $>1 \mathrm{H}$ & MDP & 2003 & 0 & 95.5 & $1.04 \mathrm{E}-05$ & 0.8 & 75105.5 & Gamma \\
\hline $\mathrm{FTR}>1 \mathrm{H}$ & MDP & 2004 & 0 & 47.0 & $1.04 \mathrm{E}-05$ & 0.8 & 75057.0 & Gamma \\
\hline $\mathrm{FTR}>1 \mathrm{H}$ & MDP & 2005 & 1 & 163.9 & 2.37E-05 & 1.8 & 75173.9 & Gamma \\
\hline $\mathrm{FTR}>1 \mathrm{H}$ & MDP & 2006 & 0 & 78.5 & $1.04 \mathrm{E}-05$ & 0.8 & 75088.5 & Gamma \\
\hline FTR $>1 \mathrm{H}$ & MDP & 2007 & 0 & 79.0 & $1.04 \mathrm{E}-05$ & 0.8 & 75089.0 & Gamma \\
\hline $\mathrm{FTR}>1 \mathrm{H}$ & MDP & 2008 & 0 & 91.1 & $1.04 \mathrm{E}-05$ & 0.8 & 75101.1 & Gamma \\
\hline $\mathrm{FTR}>1 \mathrm{H}$ & MDP & 2009 & 0 & 90.8 & $1.04 \mathrm{E}-05$ & 0.8 & 75100.8 & Gamma \\
\hline $\mathrm{FTR}>1 \mathrm{H}$ & MDP & 2010 & 0 & 82.8 & $1.04 \mathrm{E}-05$ & 0.8 & 75092.8 & Gamma \\
\hline FTR $>1 \mathrm{H}$ & MDP & 2011 & 0 & 111.3 & $1.04 \mathrm{E}-05$ & 0.8 & 75121.3 & Gamma \\
\hline $\mathrm{FTR}>1 \mathrm{H}$ & MDP & 2012 & 0 & 88.1 & $1.04 \mathrm{E}-05$ & 0.8 & 75098.2 & Gamma \\
\hline FTS & GEN & 1998 & 0 & 153.1 & $2.74 \mathrm{E}-03$ & 8.1 & 2951.1 & Beta \\
\hline FTS & GEN & 1999 & 1 & 172.2 & $3.06 \mathrm{E}-03$ & 9.1 & 2969.2 & Beta \\
\hline FTS & GEN & 2000 & 0 & 159.7 & $2.73 \mathrm{E}-03$ & 8.1 & 2957.7 & Beta \\
\hline FTS & GEN & 2001 & 0 & 142.4 & $2.75 \mathrm{E}-03$ & 8.1 & 2940.4 & Beta \\
\hline FTS & GEN & 2002 & 0 & 144.2 & $2.75 \mathrm{E}-03$ & 8.1 & 2942.2 & Beta \\
\hline FTS & GEN & 2003 & 0 & 156.9 & $2.74 \mathrm{E}-03$ & 8.1 & 2954.9 & Beta \\
\hline FTS & GEN & 2004 & 0 & 142.4 & $2.75 \mathrm{E}-03$ & 8.1 & 2940.4 & Beta \\
\hline FTS & GEN & 2005 & 0 & 134.4 & $2.76 \mathrm{E}-03$ & 8.1 & 2932.4 & Beta \\
\hline FTS & GEN & 2006 & 0 & 134.4 & 2.76E-03 & 8.1 & 2932.4 & Beta \\
\hline FTS & GEN & 2007 & 0 & 127.8 & $2.76 \mathrm{E}-03$ & 8.1 & 2925.8 & Beta \\
\hline FTS & GEN & 2008 & 0 & 155.8 & $2.74 \mathrm{E}-03$ & 8.1 & 2953.8 & Beta \\
\hline FTS & GEN & 2009 & 1 & 134.7 & $3.10 \mathrm{E}-03$ & 9.1 & 2931.7 & Beta \\
\hline FTS & GEN & 2010 & 0 & 160.3 & $2.73 \mathrm{E}-03$ & 8.1 & 2958.3 & Beta \\
\hline FTS & GEN & 2011 & 0 & 136.3 & 2.76E-03 & 8.1 & 2934.3 & Beta \\
\hline FTS & GEN & 2012 & 0 & 153.9 & $2.74 \mathrm{E}-03$ & 8.1 & 2951.9 & Beta \\
\hline FTS & MDP & 1998 & 0 & 99.4 & $9.04 \mathrm{E}-04$ & 1.9 & 2153.4 & Beta \\
\hline FTS & MDP & 1999 & 0 & 122.7 & 8.94E-04 & 1.9 & 2176.7 & Beta \\
\hline FTS & MDP & 2000 & 0 & 110.2 & 8.99E-04 & 1.9 & 2164.2 & Beta \\
\hline FTS & MDP & 2001 & 0 & 94.5 & $9.06 \mathrm{E}-04$ & 1.9 & 2148.5 & Beta \\
\hline FTS & MDP & 2002 & 0 & 121.7 & $8.95 \mathrm{E}-04$ & 1.9 & 2175.7 & Beta \\
\hline FTS & MDP & 2003 & 1 & 181.1 & 1.32E-03 & 2.9 & 2234.1 & Beta \\
\hline FTS & MDP & 2004 & 0 & 126.6 & 8.93E-04 & 1.9 & 2180.6 & Beta \\
\hline
\end{tabular}


Table 6. (continued).

\begin{tabular}{ccccccccc}
\hline \multirow{2}{*}{$\begin{array}{c}\text { Failure } \\
\text { Mode }\end{array}$} & Component & Year & $\begin{array}{c}\text { Number of } \\
\text { Failures }\end{array}$ & $\begin{array}{c}\text { Demands/ } \\
\text { Run Hours }\end{array}$ & Mean & Post A & Post B & Distribution \\
\hline FTS & MDP & 2005 & 0 & 151.3 & $8.83 \mathrm{E}-04$ & 1.9 & 2205.3 & Beta \\
\hline FTS & MDP & 2006 & 1 & 122.1 & $1.35 \mathrm{E}-03$ & 2.9 & 2175.1 & Beta \\
FTS & MDP & 2007 & 0 & 101.8 & $9.03 \mathrm{E}-04$ & 1.9 & 2155.8 & Beta \\
FTS & MDP & 2008 & 0 & 131.3 & $8.91 \mathrm{E}-04$ & 1.9 & 2185.3 & Beta \\
FTS & MDP & 2009 & 0 & 88.4 & $9.08 \mathrm{E}-04$ & 1.9 & 2142.4 & Beta \\
FTS & MDP & 2010 & 0 & 109.8 & $8.99 \mathrm{E}-04$ & 1.9 & 2163.8 & Beta \\
\hline FTS & MDP & 2011 & 0 & 92.9 & $9.07 \mathrm{E}-04$ & 1.9 & 2146.9 & Beta \\
\hline FTS & MDP & 2012 & 0 & 97.2 & $9.05 \mathrm{E}-04$ & 1.9 & 2151.2 & Beta \\
\hline
\end{tabular}

Table 7. Basic event UA trending data.

\begin{tabular}{|c|c|c|c|c|c|c|c|c|}
\hline \multirow{2}{*}{$\begin{array}{l}\text { Failure } \\
\text { Mode }\end{array}$} & \multirow[b]{2}{*}{ Component } & \multirow[b]{2}{*}{ Year } & \multirow{2}{*}{$\begin{array}{c}\text { UA } \\
\text { Hours }\end{array}$} & \multirow{2}{*}{$\begin{array}{c}\text { Critical } \\
\text { Hours }\end{array}$} & \multicolumn{4}{|c|}{ Bayesian Update } \\
\hline & & & & & Mean & Post A & Post B & Distribution \\
\hline UA & EDG & 2006 & 524.1 & 66916.8 & $7.74 \mathrm{E}-03$ & 3.0 & 384.6 & Beta \\
\hline UA & EDG & 2007 & 593.1 & 64802.1 & $9.07 E-03$ & 5.3 & 583.2 & Beta \\
\hline UA & EDG & 2008 & 779.2 & 65346.3 & $1.22 \mathrm{E}-02$ & 1.2 & 98.8 & Beta \\
\hline UA & EDG & 2009 & 506.8 & 64536.4 & $7.74 \mathrm{E}-03$ & 1.7 & 219.0 & Beta \\
\hline UA & EDG & 2010 & 1063.7 & 65868.9 & $1.60 \mathrm{E}-02$ & 1.6 & 100.3 & Beta \\
\hline UA & EDG & 2011 & 605.8 & 63380.6 & $9.89 E-03$ & 1.6 & 160.8 & Beta \\
\hline UA & EDG & 2012 & 1205.4 & 63798.2 & $1.95 \mathrm{E}-02$ & 3.6 & 183.8 & Beta \\
\hline UA & MDP & 1998 & 157.7 & 29073.5 & $3.84 \mathrm{E}-03$ & 0.6 & 168.0 & Beta \\
\hline UA & MDP & 1999 & 433.4 & 53269.1 & 8.35E-03 & 1.4 & 166.8 & Beta \\
\hline UA & MDP & 2000 & 415.7 & 64615.0 & $6.44 \mathrm{E}-03$ & 3.0 & 466.2 & Beta \\
\hline UA & MDP & 2001 & 373.4 & 64318.8 & $5.81 \mathrm{E}-03$ & 4.7 & 807.5 & Beta \\
\hline UA & MDP & 2002 & 522.4 & 65660.8 & 7.96E-03 & 2.1 & 261.5 & Beta \\
\hline UA & MDP & 2003 & 557.5 & 64216.1 & $8.95 E-03$ & 1.4 & 154.4 & Beta \\
\hline UA & MDP & 2004 & 608.1 & 66422.6 & $9.07 E-03$ & 3.8 & 420.6 & Beta \\
\hline UA & MDP & 2005 & 682.0 & 63863.9 & $1.10 \mathrm{E}-02$ & 0.5 & 43.7 & Beta \\
\hline UA & MDP & 2006 & 268.2 & 66916.8 & $3.96 \mathrm{E}-03$ & 1.2 & 295.9 & Beta \\
\hline UA & MDP & 2007 & 293.4 & 64802.1 & $4.50 \mathrm{E}-03$ & 3.1 & 691.0 & Beta \\
\hline UA & MDP & 2008 & 428.1 & 65346.3 & $6.35 E-03$ & 1.3 & 196.8 & Beta \\
\hline UA & MDP & 2009 & 194.9 & 64536.4 & $3.08 \mathrm{E}-03$ & 0.6 & 187.9 & Beta \\
\hline UA & MDP & 2010 & 579.7 & 65868.9 & $8.75 E-03$ & 1.8 & 201.1 & Beta \\
\hline UA & MDP & 2011 & 331.0 & 63380.6 & $5.55 \mathrm{E}-03$ & 2.8 & 508.6 & Beta \\
\hline UA & MDP & 2012 & 586.9 & 63798.2 & $9.60 \mathrm{E}-03$ & 1.9 & 197.8 & Beta \\
\hline
\end{tabular}


Table 8. Failure mode acronyms.

\begin{tabular}{ll}
\multicolumn{1}{c}{ Failure Mode } & \multicolumn{1}{c}{ Failure Mode Description } \\
\hline FTLR & Fail to load/run \\
FTOC & Fail to open/close \\
FTOP & Fail to operate \\
FTR $>1 \mathrm{H}$ & Fail to run greater than one hour \\
FTR $<1 \mathrm{H}$ & Fail to run less than one hour (after start) \\
FTS & Fail to start \\
SO & Spurious operation \\
UA & Unavailability (maintenance or state of another component) \\
\hline
\end{tabular}


System Study

High-Pressure Core Spray 


\section{SYSTEM DESCRIPTION}

This study documents an analysis of the operational experience of the eight BWRs listed in Table 9, all of which have an HPCS system. The analysis focused on the ability of the HPCS system to start and provide its associated emergency core cooling function for the required mission. The HPCS model is evaluated using the LLOCA and the LOOP flag sets in the SPAR model (setting the LOOP flag requires the start and run of the HPCS diesel generator). The LOOP flag set assumes all ac power is unavailable and that the HPCS system is required to perform to mitigate the effects of the LOOP initiating event. The system boundaries, data collection, failure categorization, and limitations of the study are briefly described in this section. Table 9 presents each plant's docket number and the configuration of the cooling water system for HPCS.

The emergency core cooling system in the BWRs studied typically consists of the automatic depressurization system (ADS), the HPCS system, the low-pressure core spray (LPCS) system, and the low-pressure coolant injection (LPCI) mode of the residual heat removal system. The purpose of these systems is to reestablish adequate core cooling and maintain continuity of core cooling subsequent to the entire spectrum of postulated loss-of-coolant accidents (LOCAs).

If a LOCA should occur, a low reactor water level signal or high drywell pressure signal initiates the HPCS system and its support equipment. The system can also be placed in operation manually. If the leak rate is less than the HPCS system flow rate, the HPCS system automatically stops when a high reactor water level signal shuts the HPCS injection valve. The injection valve will automatically reopen upon a subsequent low water level signal. Should the leak rate exceed the HPCS system capacity and not result in rapid depressurization of the vessel, the ADS will actuate on a lower water level signal and depressurize the vessel for the LPCS and LPCI systems to provide adequate core cooling. Should the HPCS system fail to initiate during a LOCA, the ADS vessel depressurization and subsequent LPCS and LPCI system initiations will provide adequate core cooling as a backup for the HPCS system.

The HPCS system also serves as a backup to the reactor core isolation cooling (RCIC) system in the event the reactor becomes isolated from the main condenser during operation and feedwater flow is lost. Operational transients that may require HPCS are transients that include a reactor trip and a demand for coolant injection by high-pressure makeup systems (RCIC or HPCS). For example, a transient that results in a reactor trip without a loss of feedwater may require short-term operation of the HPCS and/or other high-pressure makeup system to restore reactor pressure vessel (RPV) water level. For a transient that includes a reactor trip and a loss of feedwater, with no immediate recovery of feedwater, high-pressure makeup is required to restore and maintain RPV water level. The latter type of transient would require longer operation of high-pressure makeup compared to the transients that do not lose feedwater.

Table 9. BWR plants with an HPCS system.

\begin{tabular}{lcc}
\hline \multicolumn{1}{c}{ Plant } & Docket & Dedicated Service Water System \\
\hline Clinton 1 & 461 & Yes \\
Grand Gulf & 416 & Yes \\
La Salle 1 & 343 & Yes \\
La Salle 2 & 374 & Yes \\
Nine Mile Pt. 2 & 410 & No \\
Perry & 440 & Yes \\
River Bend & 458 & No \\
Columbia 2 & 397 & Yes \\
\hline
\end{tabular}


The primary function of the HPCS system is to maintain reactor vessel inventory for line breaks up to 1-in. nominal size. The HPCS system also provides spray cooling heat transfer during breaks in which uncovering of the core is assumed. The HPCS system pumps water through a peripheral ring spray sparger mounted above the reactor core and can supply coolant over the entire range of system operation pressures.

The HPCS system consists of a single motor-driven centrifugal pump located outside primary containment, an independent spray sparger in the reactor vessel located above the core, and associated piping, valves, controls, and instrumentation. Figure 4 is a simplified schematic of the system. The system is designed to operate using normal offsite auxiliary power. Should a loss of offsite power occur, a dedicated backup source of power is available from a diesel generator. The backup source of power (diesel generator) only affects the unreliability of the HPCS system when a loss of offsite power occurs as an initiator or during an HPCS system demand.

The principal active HPCS equipment is located outside the primary containment. Suction piping for the HPCS pump is provided from the condensate storage tank and the suppression pool. Such an arrangement provides the capability to use reactor-grade water from the condensate storage tank when the HPCS system functions to back up the RCIC system. In the event that the condensate storage tank water supply becomes exhausted or is not available, automatic switchover to the suppression pool water source ensures a cooling water supply for long-term operation of the system.

The HPCS system consists of a motor-driven centrifugal pump located outside the primary containment, a spray header located in the RPV, and associated piping, valves, controls, and instrumentation. The HPCS system also includes a dedicated backup power source consisting of a diesel generator and its support systems, including lubricating oil, fuel oil and transfer, air start, control, and engine cooling water. In addition, all the power supply components from the dedicated Division III bus to the pumps, valves, controls, and instrumentation are also considered in this study. The normal power supply to the dedicated Division III bus is considered to be outside the scope of this study; however, a risk-based discussion of the effect of a loss of offsite power on the system is included. The HPCS system is supported by a dedicated ${ }^{\mathrm{a}}$ cooling system consisting of a cooling pump and associated valves and piping. Two plants, Nine Mile Pt. 2 and River Bend, do not have a dedicated HPCS cooling water system. These two plants use the standby service water system to supply HPCS cooling water needs. The dedicated portions of the piping and valves are included in this study; the remainder of the system and the ultimate heat sink are considered outside the scope of this study. The portion of the heating, ventilating, and air-conditioning system directly supporting the HPCS system is also included in this study.

a. The ultimate heat sink for the cooling system is not dedicated to the HPCS system. 


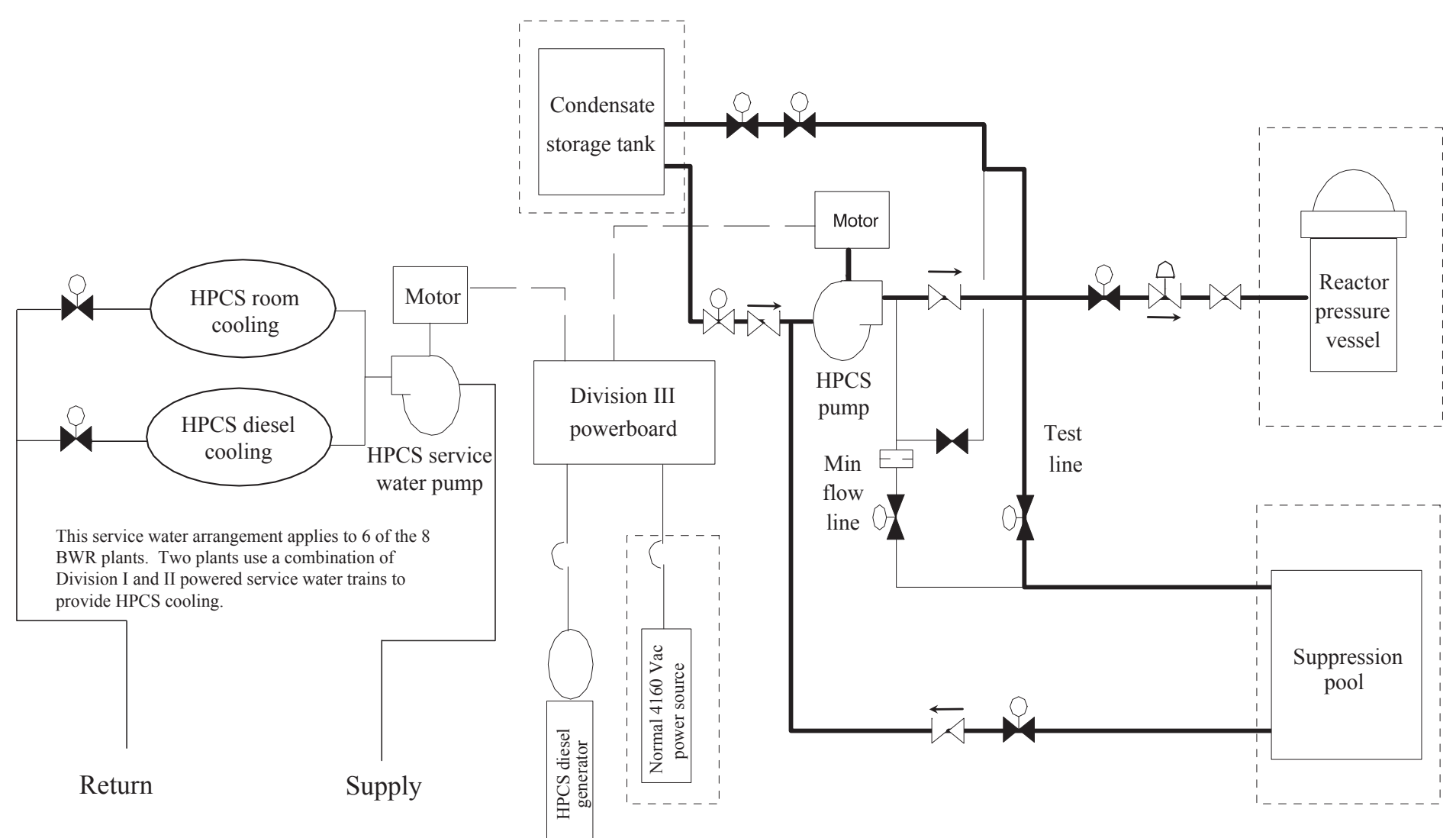

Figure 4. Simplified schematic of the HPCS system. 
System Study

High-Pressure Core Spray 


\section{REFERENCES}

1. Nuclear Regulatory Commission, Component Reliability Data Sheets Update 2010, January 2012, http://nrcoe.inl.gov/resultsdb/publicdocs/AvgPerf/ComponentReliabilityDataSheets2010.pdf

2. S.A. Eide et al., Industry-Average Performance for Components and Initiating Events at U.S. Commercial Nuclear Power Plants, Nuclear Regulatory Commission, NUREG/CR-6928, February 2007. 
System Study

High-Pressure Core Spray
2012 Update October 2013 